\title{
Sintering Behavior and Machinability Properties of Industrial Waste Materials Based Glass-Ceramics
}

\author{
G. BAYRAK ${ }^{a, *}$, E. ERCENK ${ }^{b}$, S. YILMAZ ${ }^{b}$ \\ ${ }^{a}$ Sakarya University, Department of Welding Technology, Arifiye Vocational High School, \\ 54580 Arifiye, Sakarya, Turkey \\ ${ }^{b}$ Sakarya University, Engineering Faculty, Department of Metallurgical and Materials Engineering, Esentepe \\ Campus, 54187 Sakarya, Turkey
}

\begin{abstract}
Glass-ceramics were produced by sintering method from industrial waste materials such as fly ash, blast furnace slag and boron waste. The sintering behavior and machinability of glass-ceramic compositions were investigated. Additives were added to waste materials for enhancement of machinability and sintering properties. All starting materials were mixed by ball milling for $2 \mathrm{~h}$ using alumina media. The mixed and milled powders were sieved to grain sizes smaller than $75 \mu \mathrm{m}$ and pressed at $100 \mathrm{MPa}$. The pressed samples were sintered at $900{ }^{\circ} \mathrm{C}, 1000{ }^{\circ} \mathrm{C}$ and $1100{ }^{\circ} \mathrm{C}$ for $1 \mathrm{~h}$ in an electric furnace using a heating rate of $5{ }^{\circ} \mathrm{C} / \mathrm{min}$. Some characterization tests such as X-ray diffraction (XRD), scanning electron microscopy (SEM) and machinability tests were performed on sintered samples. The results indicated that all samples exhibit good sintering and machinability properties.
\end{abstract}

DOI: 10.12693 /APhysPolA.127.1346

PACS: 61.43.Fs, 81.05.Je, 81.05.Mh, 81.20.Ev, 81.20.Wk

\section{Introduction}

Industrialization and urbanization brings huge amounts of waste materials. These materials are not only a burden to the industry, but also cause adverse effects on the environment. For this reason, we are interested in new technologies to recycle and convert waste materials into industrial materials again. This situation has great importance for protection of our environment. Glass-ceramics which are polycrystalline materials were obtained by controlled crystallization heat treatment process from suitable glass. This process usually involves two stages, namely a nucleation stage and a crystallization stage. Glass-ceramics can be obtained from various sources, such as pure oxides, natural rocks and industrial wastes (blast furnace, arc furnace, cupola furnace, flying ashes etc.). One of the major wastes of blast furnace slugs include high amounts of $\mathrm{CaO}$, $\mathrm{SiO}_{2}$ and $\mathrm{MgO}$ and small amounts of $\mathrm{MnO}$ and $\mathrm{Fe}_{2} \mathrm{O}_{3}$. Other major industrial waste of thermal power plants are flying ashes, which contain high amount of $\mathrm{SiO}_{2}$ and $\mathrm{Al}_{2} \mathrm{O}_{3}$. Due to high amount of $\mathrm{SiO}_{2}$ in industrial waste, successful production of glass-ceramic from such waste is possible. Because of brittleness of the ceramics and glass-ceramics, these are not suitable for some applications, especially when machining, such as drilling or cutting are needed. However making some modifications of glass-ceramics, such as changing chemical composition and the production methods, can provide a better machining capability [1-8]. Mica containing glass-ceramics

* corresponding author; e-mail: gunhanb@sakarya.edu.tr are preferred in some applications, such as electrical insulators and high thermal shock resist material and good machinability materials. Mica glass-ceramics are of $\mathrm{SiO}_{2}-\mathrm{MgO}-\mathrm{MgO}-\mathrm{Al}_{2} \mathrm{O}_{3}-\mathrm{K}_{2} \mathrm{O}-\mathrm{F}$ system. They have superior properties, such as remarkable cleavage, flexibility, and elasticity, enabling therefore excellent machinability. Commercial mica-type glass-ceramic, of which the main type is the fluorophlogopite-type mica, also exhibits favorable properties like heat resistance, electrical insulating, and machinability [9-11].

It the present study, the effects of sintering/crystallization temperature on the crystal phases, the machinability and the microstructure properties of glass-ceramic, obtained from industrial waste such as fly ash, blast furnace slag and boron waste were investigated.

\section{Experimental}

The chemical compositions of the raw materials and calculated compositions of glass-ceramic used in this work are given in Table I. Initially, the main composition containing $60 \%$ fly ash, $20 \%$ blast furnace slag and $20 \%$ boron waste (wt.\%) was prepared. $\mathrm{K}_{2} \mathrm{O} 5 \%$ and $\mathrm{MgF}_{2}$ $10 \%$ (wt.\%) was added to this main composition for obtaining machinability properties. The raw materials and other additives were first ground and mixed for $2 \mathrm{~h}$ by using an alumina ball mill. The mixture was sieved to a particle size fraction of $75 \pm 45 \mu \mathrm{m}$ and then uniaxial pressing was employed to shape the samples. Cylindrical samples $(\varnothing 25 \mathrm{~mm}$ ) were shaped under the $100 \mathrm{MPa}$ load and then sintered at several temperatures between 900,1000 and $1100{ }^{\circ} \mathrm{C}$, at heating rate of $5{ }^{\circ} \mathrm{C} / \mathrm{min}$ for 2 h. XRD analysis (Rigaku D/MAX, $\mathrm{CuK}_{\alpha}$ radiation) was used for the crystalline phases determination. 
The micro-structural examinations were realized by using SEM (JEOL 6060) on the sample surfaces polished and etched in the solution of $5 \mathrm{vol} . \% \mathrm{HF}$ for 1-2 min. Energy-dispersive spectrometer attachment (EDS) was employed for elemental analysis. Furthermore, machinability tests were applied to the disc shaped specimens using $5 \mathrm{~mm}$ diamond drills with $200 \mathrm{rpm}$ drilling rate under uncontrolled load.

Chemical composition of the industrial wastes and the glass-ceramic.

TABLE I

\begin{tabular}{c|c|c|c|c|c|c|c|c|c|c|c|c|c|c|c|c|c|c}
\hline \hline & $\mathrm{Al}_{2} \mathrm{O}_{3}$ & $\mathrm{~B}_{2} \mathrm{O}_{3}$ & $\mathrm{CaO}$ & $\mathrm{Cl}$ & $\mathrm{Fe}_{2} \mathrm{O}_{3}$ & $\mathrm{FeO}$ & $\mathrm{K}_{2} \mathrm{O}$ & $\mathrm{MgO}$ & $\mathrm{MnO}$ & $\mathrm{Na}_{2} \mathrm{O}$ & $\mathrm{P}_{2} \mathrm{O}_{5}$ & $\mathrm{~S}$ & $\mathrm{SiO}_{2}$ & $\mathrm{SO}_{3}$ & $\mathrm{SrO}^{\mathrm{TiO}}$ & $\mathrm{MgF}_{2}$ & $\mathrm{~L}_{2} \mathrm{O}_{2}$. \\
\hline Fly ash & 17.27 & & 1.68 & 0.002 & 12.44 & & 1.26 & 4.67 & & 0.62 & & & 56.06 & 0.6 & & & & 2.31 \\
\hline Blast furmce slag & 10.82 & & 35.32 & & & 0.3 & 0.7 & 6.47 & 2.13 & & & 0.56 & 44.1 & & & 0.5 & & \\
\hline Boron waste & 2.55 & 14.6 & 25.1 & & 0.73 & & 1.22 & 14 & & 8.43 & & & 11.42 & 0.9 & & & & 20.1 \\
\hline Glass-ceramic & 11.081 & 2.482 & 10.96 & 0.001 & 6.469 & 0.1 & 5.97 & 5.86 & 0.36 & 1.75 & 0 & 0.095 & 39.56 & 0.5 & 0.95 & 0.09 & 10 & 4.5951
\end{tabular}

\section{Results and discussion}

The XRD patterns of the samples sintered at temperatures in the range from 900 to $1100{ }^{\circ} \mathrm{C}$ are shown in Fig. 1. $\mathrm{Ca}(\mathrm{Mg}, \mathrm{Fe}) \mathrm{Si}_{2} \mathrm{O}_{6}$ [Augite (ASTM card no:24-0203)], $\mathrm{CaCO}_{3}$ [Calcite (ASTM card no:47-1743)], $\mathrm{Mg}_{9} \mathrm{~F}_{2}\left(\mathrm{SiO}_{4}\right)_{4}$ [Clinohumite (ASTM card no: 14-0009)], $\mathrm{KMg}_{3}\left(\mathrm{Si}_{3} \mathrm{Al}\right) \mathrm{O}_{10} \mathrm{~F}_{2}$ [Fluorphlogopite (ASTM card no: 16-0344)] and $\mathrm{K}_{2} \mathrm{Mg}_{6}\left(\mathrm{Si}_{0.75} \mathrm{Al}_{0.25}\right)_{8} \mathrm{O}_{20}(\mathrm{OH})_{1.8} \mathrm{~F}_{2.2}$ [Phlogopite (ASTM card no: 73-0224)] phases were determined by XRD in the sample of controlled crystallization, heat treated at $900{ }^{\circ} \mathrm{C}$ (Fig. 1a). When the same phases as Augite, Clinohumite and Phlogopite were detected in heat treated samples at $1000{ }^{\circ} \mathrm{C}$, the Calcite and Fluorphlogopite phases were not determined, as seen in Fig. 1b. In literature Calcite phase can be stable up to $950{ }^{\circ} \mathrm{C}$, this phase can transform into other phases at suitable conditions [5, 12]. In Fig. 1c, Augite, (K, Na) $\mathrm{AlSiO}_{4}$ [Nepheline (ASTM card no:120198)], $\mathrm{MgSiO}_{3}$ [Magnesium Silicate (ASTM card no:471750)], $\mathrm{Ca}_{4} \mathrm{Fe}_{14} \mathrm{O}_{25}$ [Calcium iron oxide (ASTM card no:13-0395)] and $\mathrm{Ca}(\mathrm{Mg}, \mathrm{Al})(\mathrm{Si}, \mathrm{Al})_{2} \mathrm{O}_{6}$ [Diopside (ASTM card no:41-1370)] phases have appeared but the Clinohumite, Fluorphlogopite and Phlogopite phases have disappeared. Fluorphlogopite phase has great importance for machinability. Increase in sintering temperature caused formation of weak Fluorphlogopite peaks. This phase was observed in the XRD patterns of the samples sintered at 900 and $1000{ }^{\circ} \mathrm{C}$. Above $1000{ }^{\circ} \mathrm{C}$, intensities of these peaks, but also intensities of all other peaks have decreased with temperature. Machinable glass-ceramic under the commercial trademark of MACOR consists of Fluorphlogopite mica in a borosilicate glass matrix. The XRD results are in good agreement with the literature [13]. The crystallization temperatures of Fluorphlogopite and Phlogopite phase were around $900-1000{ }^{\circ} \mathrm{C}$ and it is probable, that the increase in temperature has caused melting of these crystalline phases and their transformation into other phases.

Table II exhibits detected crystalline phases and the macro images before and after machinability tests. As seen from Table II, machinability test was performed for all samples, successfully. As can be seen in the macro images, firing shrinkage and also darkening of color was observed clearly with the increase of temperature.

Figure 2 shows the SEM images of the samples sintered

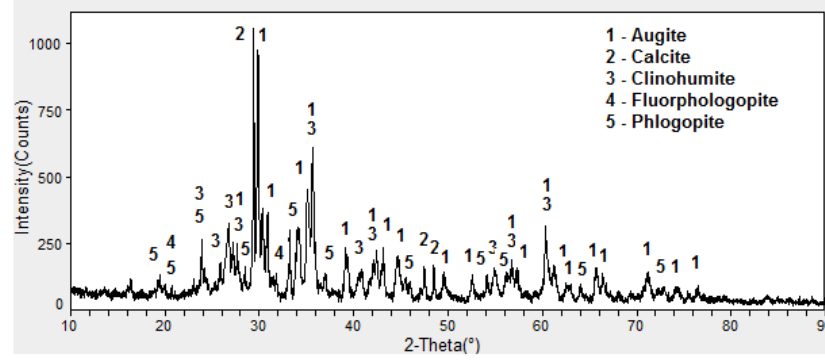

(a)

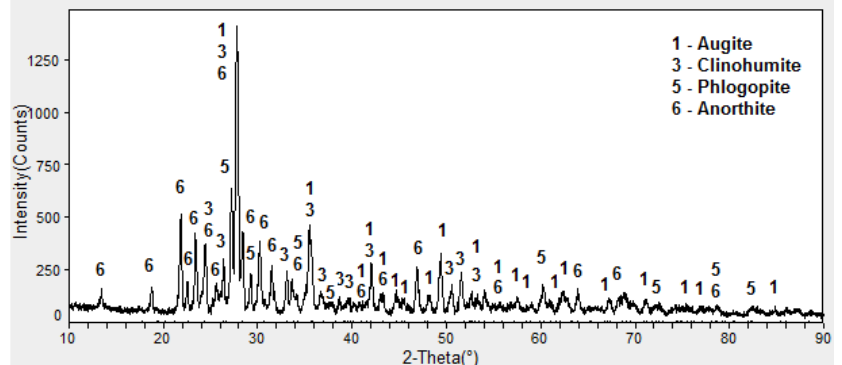

(b)

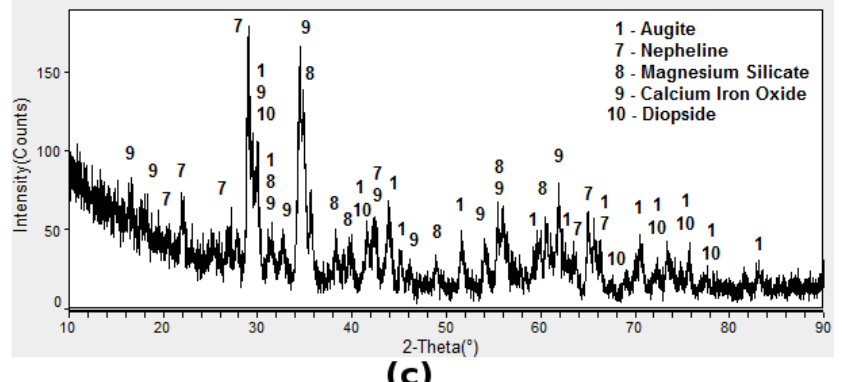

Fig. 1. XRD patterns of the samples sintered at temperatures of a) $900{ }^{\circ} \mathrm{C}$, b) $1000{ }^{\circ} \mathrm{C}$ and c) $1100{ }^{\circ} \mathrm{C}$.

at 900 and $1000{ }^{\circ} \mathrm{C}$. The results obtained from EDS analysis are in good agreement with the XRD analysis results. The grains marked with $(*)$ in both Fig. $2 \mathrm{a}$ and $2 \mathrm{~b}$ are common images for mica glass-ceramic, including flour, it was presented by Höche as mica plates [14].

\section{Conclusion}

The main objective of this study was to produce machinable glass-ceramic materials from industrial wastes, such as fly ash, blast furnace slag and boron 
TABLE II

The macro images and detected crystalline phases of samples according to sintering temperature.

\begin{tabular}{|c|c|c|c|}
\hline \multirow{2}{*}{$\begin{array}{c}\text { Sintering } \\
\text { temperature }\end{array}$} & \multirow{2}{*}{$\begin{array}{c}\text { Detected } \\
\text { phases }\end{array}$} & \multicolumn{2}{|c|}{ Machining test } \\
\hline & & Before & After \\
\hline $900{ }^{\circ} \mathrm{C}$ & $\begin{array}{c}\text { Augite, } \\
\text { Calcite, } \\
\text { Clinohumite, } \\
\text { Fluorphlogopite, } \\
\text { Phlogopite }\end{array}$ & & \\
\hline $1000{ }^{\circ} \mathrm{C}$ & $\begin{array}{c}\text { Anorthite, } \\
\text { Augite, } \\
\text { Clinohumite, } \\
\text { Phlogopite }\end{array}$ & & \\
\hline $1100{ }^{\circ} \mathrm{C}$ & $\begin{array}{c}\text { Augite, Diopside, } \\
\text { Calcium Iron } \\
\text { Oxide, } \\
\text { Magnesium } \\
\text { Silicate, } \\
\text { Nepheline }\end{array}$ & $0 \mathrm{om}-1$ & \\
\hline
\end{tabular}

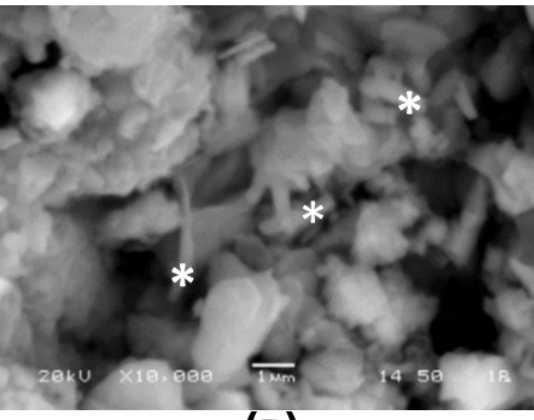

(a)

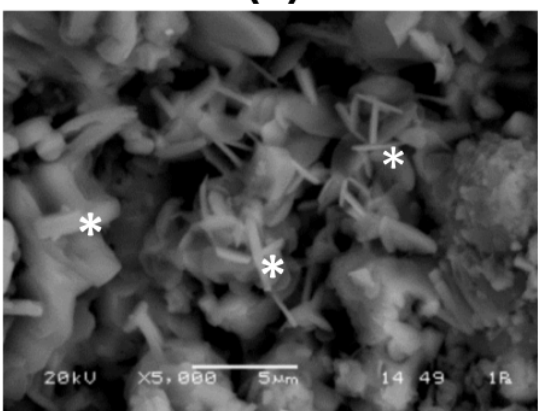

(b)

Fig. 2. SEM images of the samples sintered at a) 900 and b) $1000{ }^{\circ} \mathrm{C}$.

waste, by sintering method. Whereas Fluorphlogopite, Phlogopite and Clinohumite phases were obtained in the sample sintered at $900{ }^{\circ} \mathrm{C}$, the Phlogopite and Clinohumite phases were determined in samples sintered at $1000{ }^{\circ} \mathrm{C}$. These phases disappeared at $1100{ }^{\circ} \mathrm{C}$ and Augite, Diopside, Calcium Iron Oxide, Magnesium Silicate and Nepheline phases have occurred. Machinability test was performed successfully for all samples. When macro images of samples were scrutinized, firing shrink- age and also darkening of color was observed, which were clearly depending on increase in sintering temperature.

\section{References}

[1] A.A. Francis, Mat. Research Bull. 41, 1146 (2006).

[2] S. Yilmaz, G. Bayrak, S. Sen, U. Sen, Mat. \&3 Design. 27, 1092 (2006).

[3] S. Yilmaz, O.T. Ozkan, V. Gunay, Ceram. Int. 22 , 477 (1996).

[4] G. Bayrak, S. Yilmaz, Acta Phys. Pol. A. 125, 623 (2014).

[5] E. Ercenk, S. Yilmaz, Acta Phys. Pol. A. 125, 629 (2014).

[6] D.U. Tulyaganov, M.J. Ribeiro, J.A. Labrincha, Ceram. Int. 28, 515 (2002).

[7] M. Erol, S. Kucukbayrak, A.E. Mericboyu, M.L. Ovecoglu, Jour. Eur. Cer. Soc. 21, 2835 (2001).

[8] R.D. Rawlings, J.P. Wu, A.R. Boccaccini, Jour. Mat. Sci. 41, 733 (2006).

[9] A.M. Nassar, E.M.A. Hamzawy, F.M. Hafez, S.S. El Dera, C. Rüssel, Ceram. Int. 38, 1921 (2012).

[10] D.U. Tulyaganov, S. Agathopoulos, H.R. Fernandes, J.M. Ventura, J.M.F. Ferreira, Jour. Euro. Ceram. Soc. 24, 3521 (2004).

[11] S. Taruta, T. Ichinose, T. Yamaguchi, K. Kitajima, Jour. Non-Cryst. Solids. 352, 5556 (2006).

[12] J. Wu, Z. Li, Y. Huang, F. Li, Ceram. Int. 39, 7743 (2013).

[13] J. Henry, R.G. Hill, Jour. Non-Cryst. Solids. 319 , 13 (2003).

[14] T. Höche, S. Habelit z, I.I. Khodos, J. Cryst. Growth. 192, 185 (1998). 